Discussion Paper No. 09-053

\title{
The KfW/ZEW Start-up Panel: Design and Research Potential
}

Helmut Fryges, Sandra Gottschalk, and Karsten Kohn

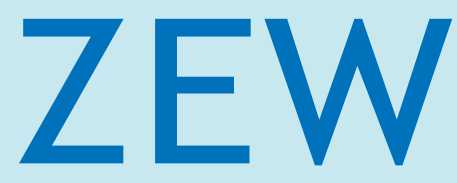

Zentrum für Europäische Wirtschaftsforschung $\mathrm{GmbH}$

Centre for European

Economic Research 
Discussion Paper No. 09-053

\title{
The KfW/ZEW Start-up Panel: Design and Research Potential
}

\author{
Helmut Fryges, Sandra Gottschalk, \\ and Karsten Kohn
}

Download this ZEW Discussion Paper from our ftp server:

ftp://ftp.zew.de/pub/zew-docs/dp/dp09053.pdf

Die Discussion Papers dienen einer möglichst schnellen Verbreitung von neueren Forschungsarbeiten des ZEW. Die Beiträge liegen in alleiniger Verantwortung der Autoren und stellen nicht notwendigerweise die Meinung des ZEW dar.

Discussion Papers are intended to make results of ZEW research promptly available to other economists in order to encourage discussion and suggestions for revisions. The authors are solely responsible for the contents which do not necessarily represent the opinion of the ZEW. 


\section{Non-technical Summary}

Existing data sets on firm formations in Germany suffer from various shortcomings that prohibit sound analyses of new firms' development over time. Therefore, the Centre for European Economic Research (ZEW), KfW Bankengruppe and Creditreform are cooperating to form a start-up panel for Germany. In each wave of the KfW/ZEW Start-up Panel computer-aided telephone interviews (CATI) are conducted with about 6,000 newly founded firms. The average length of an interview amounts to 25 minutes.

The random sample of the KfW/ZEW Start-up Panel is drawn from the database of Creditreform, the largest credit rating agency in Germany. Three stratification criteria are applied in order to construct the sample of the start-up panel: year of firm formation, sector, and whether or not the firm has been promoted by KfW Bankengruppe. In each year, a random sample of firms which have been founded within three years prior to the year of the survey is drawn. The start-up panel covers almost all industry sectors. Half of the firms included in the sample operate in a hightechnology industry. Since the KfW/ZEW Start-up Panel intends to track the development of newly founded firms over time, firms that already participated in the survey will be contacted during the subsequent years as long as they are eight years of age or younger.

In order to fully exploit the potential of the longitudinal nature of the KfW/ZEW Start-up Panel, two different questionnaires are applied in each year's survey. Firms contacted for the first time are asked a broad range of structural information using a baseline questionnaire. A follow-up questionnaire is targeted to firms which have already participated in previous waves of the panel; it has a particular focus on changes within the participating firms over time. Research issues that will be analysed based on the panel include human capital of firm founders, strategies for market entry, innovation and R\&D activities, labour demand, and investment and financing strategies of young firms. Another asset of the panel originates from the fact that staff members of Creditreform will directly investigate all firms which cannot be re-contacted in the course of the telephone survey. This way we will be able to reliably identify the survival status of all firms that ever participated in the panel, and to distinguish between firm mortality and other reasons preventing a repeated contact with a firm (e.g., change of firm name, change of telephone number).

The utilisation of the firm records is restricted for scientific purposes only. The rules of data protection guarantee that survey data will not be used for credit negotiations or credit ratings of the participating firms. Anonymised scientific-use-files of the yearly surveyed cross-sections of the KfW/ZEW Start-up Panel will be provided to external scientists with a respective delay of three years. 


\section{Nicht-technische Zusammenfassung}

Existierende Datenbanken zu Unternehmensgründungen in Deutschland weisen verschiedene Mängel auf, die eine gründliche Analyse der Entwicklung neu gegründeter Unternehmen im Zeitablauf unmöglich machen. Aus diesem Grund kooperieren das Zentrum für Europäische Wirtschaftsforschung (ZEW), die KfW Bankengruppe sowie die Creditreform Wirtschaftsforschung beim Aufbau eines Gründungspanels für Deutschland. In jeder Welle des KfW/ZEWGründungspanels werden computergestützte Telefoninterviews (CATI) mit rund 6.000 neu gegründeten Unternehmen geführt. Die durchschnittliche Länge eines Interviews beträgt 25 Minuten.

Die Zufallsstichprobe des KfW/ZEW-Gründungspanels wird aus der Datenbank der Creditreform, Deutschlands größter Kreditauskunftei, gezogen. Die drei Schichtungskriterien der Stichprobe sind: das Gründungsjahr des Unternehmens, die Branche, und ob das Unternehmen durch die KfW Bankengruppe gefördert wurde oder nicht. Jährlich wird eine Zufallsstichprobe von maximal drei Jahre alten Unternehmen gezogen. Das Gründungspanel umfasst nahezu alle Branchen. Die Hälfte der in der Stichprobe enthaltenen Unternehmen stammt aus Hochtechnologiebranchen. Da das KfW/ZEW-Gründungspanel die Entwicklung von Gründungen über die Zeit verfolgen will, werden Unternehmen, die bereits an der Umfrage teilgenommen haben, auch in den nachfolgenden Jahren kontaktiert. Unternehmen, die älter als acht Jahre sind, werden nicht weiter befragt.

Um den langfristigen Charakter des KfW/ZEW-Gründungspanels vollständig auszunutzen, werden jedes Jahr zwei verschiedene Fragebögen erstellt. Der Fragenkatalog für die erstmalige Befragung eines Unternehmens umfasst ein breites Spektrum an strukturellen Informationen. Bei Unternehmen, die bereits an früheren Panelbefragungen teilgenommen haben, ist der Fragebogen auf Veränderungen im Unternehmen über die Zeit fokussiert. Forschungsfragen, die basierend auf den Daten des Gründungspanels analysiert werden, umfassen das Humankapital der Gründerpersonen, Markteintrittsstrategien, Innovationen und F\&E-Aktivitäten, Arbeitsnachfrage sowie Investitionsund Finanzierungsstrategien junger Unternehmen. Ein weiterer Vorteil des Gründungspanels beruht auf der Tatsache, dass Mitarbeiter von Creditreform den Überlebensstatus derjenigen Unternehmen recherchieren werden, die im Verlauf der Telefonbefragungen nicht mehr kontaktiert werden können. Auf diese Weise kann zwischen Unternehmenssterblichkeit und anderen Gründen, welche einen wiederholten Kontakt mit einem Unternehmen verhindern können (z.B. Änderung des Unternehmensnamens, Änderung der Telefonnummer), unterschieden werden.

Die Verwendung der Unternehmensdaten ist auf rein wissenschaftliche Zwecke beschränkt. Die Datenschutzregelungen garantieren, dass die Daten nicht für Kreditverhandlungen oder Ratings verwendet werden. Ein anonymisierter Scientific-use File der jährlichen Querschnittsdaten wird externen Wissenschaftlern drei Jahre nach der jeweiligen Befragung zur Verfügung gestellt. 


\title{
The KfW/ZEW Start-up Panel: Design and Research Potential
}

\author{
Helmut Fryges * \\ Sandra Gottschalk ** \\ Karsten Kohn ***
}

Extended Version, August 2009

\begin{abstract}
So far, there has been no data set which observes firm formations in Germany not only on a cross-sectional basis using one-time surveys, but continuously over a number of years. Therefore, the Centre for European Economic Research (ZEW), KfW Bankengruppe and Creditreform set up a panel study of newly founded firms in Germany: the KfW/ZEW Start-up Panel. In each of the yearly panel waves computer-aided telephone interviews (CATI) are conducted with about 6,000 start-up firms from almost all industries. The KfW/ZEW Start-up Panel will for the first time enable profound analyses of the temporal development of newly founded firms, including studies of firm survival. This paper describes the design of the KfW/ZEW Start-up Panel. The survey's research potential is illustrated using data from the first panel wave conducted in the year 2008. Data access for external researchers and data protection issues of the confidential micro data are discussed.
\end{abstract}

Keywords: firm foundation, micro data, firm data, panel data, Germany.

Acknowledgement: We thank Hardy Gude, Kerstin Kiehl, Georg Licht, Kathrin Müller, Michaela Niefert, Hannes Spengler, Margarita Tchouvakhina, and Katrin Ullrich for fruitful discussions and suggestions. All errors are our sole responsibility.

* Corresponding author: Centre for European Economic Research, Department of Industrial Economics and International Management, P.O. Box 103443, D-68034 Mannheim, Germany, e-mail: fryges@zew.de

** Centre for European Economic Research, Department of Industrial Economics and International Management, P.O. Box 103443, D-68034 Mannheim, Germany, e-mail: gottschalk@zew.de

*** KfW Bankengruppe Frankfurt and IZA Bonn. KfW, Economics Department, Palmengartenstr. 5-9, D-60325 Frankfurt am Main, Germany, e-mail: karsten.kohn@kfw.de 


\section{Introduction}

So far, there has been no data set which observes firm formations in Germany not only on a cross-sectional basis using one-time surveys, but continuously over a number of years. A couple of related data sets are targeted on examining entrepreneurship activities in Germany, but all hitherto existing data sets suffer from various shortcomings that prohibit sound analyses of new firms’ development over time.

Data from existing population surveys like the Global Entrepreneurship Monitor (GEM, Sternberg et al. 2007) or the KfW Start-up Monitor (KfW-Gründungsmonitor, Kohn and Spengler 2009, Tchouvakhina and Hofmann 2003/04), which are prominent in the field of entrepreneurship research, do not follow a panel design in the narrow sense-that is, they do not track the same individuals over time but rather draw new random samples for each survey wave. Moreover, population surveys are designed to give a representative picture of start-up activities in the population. Random samples of individuals are surveyed in order to determine whether or not the individuals have been involved in starting a new business. Therefore, the statistical units of theses surveys are individual persons and not firms. One advantage of population surveys is that they enable the analysis of individuals' activities and possible obstacles faced by (potential) starters in preparation for their business start-up. However, since population surveys sample both entrepreneurs and the majority of individuals who do not start a firm, even large-scale population surveys include only a small number of businesses and thus offer a more limited scope for structural analyses of firm-specific characteristics than firm-level surveys.

Existing firm-level panel data sets for Germany like the Mannheim Innovation Panel (Mannheimer Innovationspanel, Janz et al. 2001) of the Centre for European Economic Research (ZEW) or the KfW SME Panel (KfW-Mittelstandspanel, Lo and Reize 2008) do not sufficiently cover start-ups since they focus on the stock of firms. The establishment panel of the German Federal Employment Agency (IAB Betriebspanel, Bellmann et al. 1991) is not optimal, since it does not observe firms before they employ their first employee who is subject to social insurance contributions. As most new firms do not have any employees subject to social insurance contributions during their start-up period, the large segment of very small firms is excluded from this data set. Other existing firm-level panels cover selective regions and industries only. For example, the Start-up Panel North-Rhine Westphalia (Gründungspanel 
$N R W$ ) is restricted to start-ups in the handicrafts sector in the German state of North-Rhine Westphalia (Schulte 2001).

The Mannheim Enterprise Panel (Mannheimer Unternehmenspanel, Almus et al. 2000) build up by the ZEW is based on the database of Creditreform, Germany's largest credit rating agency. This process-generated data set comprises regularly updated information on start-ups which are located in Germany. However, there are a lot of research questions that cannot be answered using solely the information available in the Mannheim Enterprise Panel. For example, the data neither include detailed information on the firms' founders nor on innovation activities or the firms' financial structure. Since the latter variables are regarded as decisive for the performance of young firms, the Mannheim Enterprise Panel can only give limited insight into the factors influencing firm growth and survival.

In order to close the aforementioned gaps in the availability of data on newly founded firms, the Centre for European Economic Research (ZEW), KfW Bankengruppe and Creditreform are cooperating to form a start-up panel for Germany. In each wave of the KfW/ZEW Start-up Panel (KfW/ZEW-Gründungspanel) computer-aided telephone interviews (CATI) are conducted with about 6,000 newly founded firms from almost all industries. The KfW/ZEW Start-up Panel will for the first time enable researchers to conduct profound analyses of the temporal development of newly founded firms, including studies of start-up survival or failure. Moreover, the KfW/ZEW Start-up Panel is representative for the entire area of Germany and covers the lion's share of all industries.

The first panel wave was conducted in spring 2008. In the survey data was collected data on firms' founders, strategies of market entry, innovation activity, number and structure of employees and employment fluctuation, and firms' financing structure. Major results of the first survey are published in the 2008 start-up panel report (Gottschalk et al. 2008).

This paper describes the design and the research potential of the KfW/ZEW Start-up Panel. It is organised as follows. Section 2 provides details on the sampling design, including the underlying population and the stratification procedure used to build the gross sample, as well information on the net sample and the interviewing process. Section 3 illustrates the research potential of the KfW/ZEW Start-up Panel using results from the first panel wave. Issues of data protection of the confidential micro data and ways of data access for external researchers are discussed in section 4 . Section 5 concludes with a brief summary. 


\section{Survey Design}

The description of the survey design starts with an explanation of the parent population from which the start-up panel's random sample is drawn (subsection 2.1). The stratification procedure and the composition of the gross and the net sample are described in the consecutive subsections 2.2 and 2.3. The set-up of the data collection process (interviews, baseline questionnaire and follow-up questionnaire) is specified in subsection 2.4. Subsection 2.5 addresses the problem of non-response and panel attrition, and sketches how participating firms' survival status will be identified.

\subsection{Creditreform Data as Population}

The sample of the KfW/ZEW Start-up Panel is drawn from the database of Creditreform, the largest credit rating agency in Germany. Creditreform collects data in a decentralised way, currently by 130 offices from all over Germany but in accordance with a standard data collection procedure. The statistical units of the Creditreform database are legally independent firms. The database includes, inter alia, the name and the address of the firm, legal form, industry classification, foundation date and information regarding insolvency procedures. In this way, Creditreform has the most comprehensive database of German firms at its disposal. The database is provided to the ZEW for research purposes (see Almus et al. 2000 for a detailed description of the Creditreform database). The KfW/ZEW Start-up Panel uses the Creditreform database as the parent population for each year's random sample of newly founded firms.

In the literature on entrepreneurship research there are different concepts of what is regarded as a firm formation. Due to the use of the Creditreform database, the KfW/ZEW Start-up Panel follows a narrow definition. A firm is filed in the Creditreform database only if it actively participates in business life, e.g., by taking out a loan, employing workers or renting business rooms. Accordingly, the year of firm formation is defined as the year in which a firm starts its regular business activities. In other words, the KfW/ZEW Start-up Panel applies an economic definition of firm foundation, whereas official statistics based on business registrations (Gewerbeanzeigenstatistik) do not necessarily require any business activities of registered firms.

The use of the Creditreform database as the parent population of the KfW/ZEW Start-up Panel implies that firms in the sample are run by at least one full-time entrepreneur. In fact, there are a high number of entrepreneurs in Germany who start a business as a sideline activ- 
ity in addition to a job in dependent employment (Kohn and Spengler 2009). However, most of these part-time entrepreneurs - as they are recorded, for instance, in the KfW Start-up Monitor (Kohn and Spengler 2009)—have only small financing needs and do not take out loans since they finance their firms with own funds. They mostly start without employees and do not rent additional business rooms since business activities are mainly carried out in the entrepreneur's house or apartment. Therefore, part-time entrepreneurs are not included in the Creditreform database-and consequently not in the KfW/ZEW Start-up Panel, either.

\subsection{Stratification}

Using the Creditreform database, the ZEW research team identifies those firms that are suitable for the survey and draws a random sample of firms that will be contacted in the course of the survey. Three stratification criteria are applied in order to construct the sample of the KfW/ZEW Start-up Panel: year of firm formation, sector, and whether or not the firm has been promoted by KfW Bankengruppe, Germany’s largest state-owned promotional bank. Each year, a random sample of firms is drawn which have been founded during the three years prior to the year of the survey. The choice of the three-year period is motivated by our aim to guarantee a sufficiently high number of start-ups from high-technology (manufacturing) industries in each cross-sectional wave of the panel. Since the annual number of hightech manufacturing start-ups in Germany is rather small (cf. Metzger et al. 2008), we decided to include three foundation cohorts into the parent population of each year's random sample. On the other hand, older firms are excluded because we want to identify firm-specific characteristics at the time of firm formation. The larger the time lag between the year of firm formation and the first survey interview, the less precise is the information about the crucial start-up period. For instance, firms often face changes in ownership as they mature-and this renders it difficult to survey comprehensive data on the founder if she is no longer engaged in her business. Therefore, firms must be three years of age or younger when they are interviewed for the first time.

The second stratification criterion is the industry sector the firm is operating in. The start-up panel covers almost all industry sectors. ${ }^{1}$ The sample is stratified by ten industrial sectors. Table 1 shows the industry composition using NACE (revision 1) code. Four out of ten sectors encompass high-technology industries whereas non-technical industries are assigned to the remaining six sectors. Start-ups from high-technology industries are expected to play a

\footnotetext{
${ }^{1}$ The only sectors excluded are agriculture, mining and quarrying, electricity, gas and water supply, health care, and the public sector.
} 
particularly important role with respect to innovation, structural change and job creation (see, e.g., Birch 1989, Audretsch and Fritsch 2003). Therefore, newly-founded technology-based firms are overrepresented in the start-up panel's sample. One half of the firms included in both the gross sample and the net sample operate in a high-technology industry.

$<<<$ Table 1 near here $>>>$

The third stratification criterion of the start-up panel is the dummy variable whether or not a firm has been promoted by KfW Bankengruppe (KfW). Names and addresses of firms supported by KfW are matched with the Creditreform database applying a self-developed heuristic search engine. In this way, firms that have received financial support from KfW are identified in the Creditreform database. Firms with financial support from KfW are also overrepresented in the start-up panel's sample. In each stratification cell defined by the year of firm formation and the industrial sector a maximum of $50 \%$ of the firms in both the gross and the net sample have been financially supported by KfW. The large number of financially supported firms in the sample of the start-up panel enables researchers from KfW to suggest on how to improve the bank's support programmes and to better adapt them to the needs of young firms.

\subsection{Gross and Net Sample}

The target size of each year's net sample, i.e., the number of realised full interviews, totals to an average of 6,000 firms. During the initial years of the start-up panel we plan to realise a slightly smaller number of interviews. For instance, 5,500 firms were interviewed in the year 2008 and we plan to conduct interviews with 5,600 start-ups in 2009. The target size of the net sample will gradually increase over time because firms which have been interviewed in previous years remain in the gross sample. This means that older firms are added to the random sample of start-ups from the three foundation cohorts prior to the year of the survey, leading to an increase in the number of interviews over the next six years. ${ }^{2}$ From 2014 onwards, there will be no further increase in the sample size because the first foundation cohort, i.e., firms founded in 2005, will drop out of the sample (see also subsection 2.4 below).

Based on experience from other studies, we anticipated a response rate (i.e., the share of interviewed firms in all contacted firms) of approximately 20 percent for those firms that have

\footnotetext{
${ }^{2}$ The target size of the net sample could be held constant if we reduced the number of planned interviews with newly founded firms to the same amount as that of interviews conducted with older firms that already participated in previous waves. However, since we are interested in guaranteeing a sufficiently high number of interviews with firms that will be founded in future years, we allowed for a gradual increase in the size of the net sample instead.
} 
not been interviewed before. Therefore, the gross sample (i.e., the number of firms drawn from the Creditreform database) of the start-up panel's first wave was about five times as high as the planned sample size of the net sample. Table 2 shows the composition of the gross sample drawn for the survey conducted in 2008, differentiated by the stratification criteria industrial sector and year of firm formation. 25,551 firms were drawn from the Creditreform database, 21,587 of which were eventually contacted. As mentioned above, the number of firms from high-technology manufacturing industries is relatively small in the Creditreform database. This mirrors the fact that there are only a small number of newly-founded technology-based manufacturing firms in Germany. Therefore, we decided to include all of these firms that have been recorded by Creditreform in the start-up panel's gross sample in order to obtain a sufficiently high number of interviews with technology-based manufacturing firms. Coverage rates in the other sectors are necessarily smaller. Nevertheless, we collect data on a considerable number of start-ups in these sectors.

$$
<<<\text { Table } 2 \text { near here }>>>
$$

\subsection{Interviews and Questionnaires}

The interviews of the start-up panel are currently conducted by the Zentrum für Evaluation und Methoden (ZEM) of the University of Bonn. Each interview is introduced by a screening procedure in order to determine whether or not the contacted firm is eligible for inclusion in the start-up panel. Firms that are contacted for the first time are excluded from the survey if the interviewee indicates that her firm was not founded in the three-year period prior to the year of the survey or if the firm was founded as a de-merger or a subsidiary of another firm. The latter criterion is applied because we are only interested in the development of economically independent firms. The interview is also abandoned if it is impossible to talk to an interviewee who is engaged in the management of the contacted firm. Firms that participated in at least one survey in the past will no longer be interviewed if the firm has been taken over by another company and thus the firm no longer being economically independent. The surveys of the start-up panel are carried out using computer-aided telephone interviews (CATI). The average length of an interview amounts to 25 minutes.

In the course of the 2008 survey, 5,508 full interviews were realised, which corresponds to a response rate of just below 26 percent. The composition of the net sample, differentiated by 
industry sector and year of firm formation, is also depicted in Table 2. Table 3 specifies the response code of all firms that were contacted in $2008 .^{3}$

$$
<<<\text { Table } 3 \text { near here }>>>
$$

The KfW/ZEW Start-up Panel intends to track the development of newly founded firms over the first years after firm formation. Firms that have already participated in the survey will be contacted in subsequent years as long as they are eight years of age or younger. Older firms will no longer be contacted. This means, for example that a firm founded in 2005 will be interviewed for the last time in 2013; firms from the 2006 cohort will be contacted ultimately in 2014, and so forth. The eight-year horizon comprehensively covers the first phase of a firm's life cycle. International empirical evidence suggests that hazard rates (i.e., the probability of market exit within one year, given that the firm was still operating at the beginning of that year) usually exhibit a local maximum when firms are between two and four years of age (cf. van Praag 2003, Brüderl et al. 2007). However, in some industries-depending on the life cycle stage and the technological intensity of the industry-hazard rates may exhibit their local maximum when firms are seven or eight years of age (Agarwal and Audretsch 2001, Prantl 2001). Thus, the start-up panel spans the crucial first years of a firm's existence that are characterised by a particularly high risk of failure before young firms’ hazard rates converge towards those of established firms.

In order to fully exploit the potential of the longitudinal nature of the KfW/ZEW Start-up Panel, two different questionnaires are applied in each year's survey. One questionnaire is addressed to firms which participate in the survey for the first time. This questionnaire collects detailed information on structural characteristics of firms at the time of their start-up. The second questionnaire is targeted to firms which have already participated in previous waves. This follow-up questionnaire has a particular focus on changes within the participating firms over time. There is a significant overlap of the two questionnaires, guaranteeing that we can compare the characteristics of new participants and those firms that have already participated in at least one survey wave in the past. Basic aspects such as sales and employment numbers, and investment and financing behaviour are collected in each year's questionnaires. Along with these standard questions that remain the same every year, additional main focus

\footnotetext{
${ }^{3}$ About one quarter (24\%) of all contacted firms indicated a foundation year other than 2005, 2006 or 2007. One main reason as to why the foundation year indicated by firm representatives deviates from the foundation year recorded in the Creditreform database is that Creditreform in most cases measures the year of start-up by the date of registration in the trade register, whereas entrepreneurs often regard the year in which they started to prepare the set-up of their new business as the year of firm formation.
} 
themes are included each year into the questionnaires. The 2008 survey, for instance, had a main focus on firms' strategies for market entry.

\subsection{Non-Response and Panel Attrition}

The construction of a panel data set like the KfW/ZEW Start-up Panel requires that firms repeatedly participate in the annual surveys. However, some firms who have participated in former waves will refuse to attend future waves (non-response). If a firm denies an interview in two subsequent years, it will be excluded from the start-up panel's gross sample and will not be contacted again.

In addition to simple non-response, participants of former surveys sometimes cannot be contacted in the course of a future survey. It is a common problem of all firm surveys that very little is known about the fortune of firms that drop out from the survey (panel attrition). Some of these firms might have exited from the market. However, firms might also have changed their name, their legal form or their telephone number, they might have been taken over by another firm or they might have moved to another location. Therefore, if a firm cannot be contacted it will be generally difficult to distinguish firm death and other events that prevent repeated contact.

In some cases, non-surviving firms can be detected by an identifier in the underlying Creditreform database. Yet this measure may be available with a large time lag only. In some other cases, information on liquidated firms may be obtained from participating entrepreneurs if the telephone number is still in order after firm closure. Regarding the majority of opaque nonsurvivors, though, the KfW/ZEW Start-up Panel offers an important additional alternative. Starting in the year 2010, Creditreform will directly investigate all firms which no longer respond to the telephone survey and for which there is no indication of closure in the Creditreform database. Due to the decentralised organisational structure of Creditreform, staff members in each of the 130 offices have a profound knowledge of their local market, which facilitates the determination of the actual survival status of the firms in question.

\section{Research Potential}

The sampling strategy and the survey design of the KfW/ZEW Start-up Panel offer three unique assets for research. First, the large cross-sectional dimension opens up the possibility of sound investigations of the characteristics of start-ups at an early stage. What is more, the oversampling of start-ups in high-tech sectors of the economy allows for detailed analyses of 
these firms and comparisons of start-ups from different sectors. Second, the longitudinal dimension of the panel enables researchers to analyse start-up success in the crucial first years of firms' existence. Start-up success comprises firm survival as well as, e.g., sales and employment growth. As a third asset, the extensive questionnaire combines information on the firms and personal information about the founders themselves (resp., the team of founders). The set-up thus takes account of the particular importance of the entrepreneur in start-ups and young firms (Kohn and Spengler 2008b).

The following subsections 3.1 to 3.4 illustrate the cross-sectional potential and long-run prospects of the KfW/ZEW Start-up Panel, drawing on the questionnaire and results from the first panel wave conducted in 2008 (Gottschalk et al. 2008). Subsection 3.5 then touches upon analyses of new firms' survival.

\subsection{Strategies for Market Entry of New Firms}

Defining and knowing the relevant market is a key prerequisite for successful market entry. How many competitors are there in the market? Should entrants expect fierce competition? First results from the KfW Start-up Panel indicate that about one half (56\%) of all start-ups face more than 20 competitors at market entry, while about one fourth (24\%) only faces less than 6 competitors (Gottschalk et al. 2008). A cross-industry comparison reveals that the number of competitors is relatively low in manufacturing industries. As production in manufacturing is particularly capital-intensive, manufacturing industries exhibit a relatively large optimal firm size. Due to high capital requirements, entry barriers for new manufacturing firms might be expected to be relatively high. In most service sectors, though, one should expect lower entry barriers due to lower capital intensities and a lower average firm size. The larger number of competitors in service sectors is in line with this notion.

Heterogeneity in the characteristics of relevant product markets is clearly linked to different entry strategies. Porter (1980) distinguishes 3 generic strategies: cost and price leadership, product differentiation, and a niche strategy in small market segments with few (or no) competitors. Participants in the KfW/ZEW Start-up Panel were asked to assess different elements of strategy as to their competitive advantage.

$<<<$ Figure 1 near here $>>>$

As shown in Figure 1, most start-ups consider the quality of their products and customisation as their individual strength: Almost $70 \%$ of all start-ups name these dimensions as a great competitive advantage. On the other hand, merely 34\% consider their product price a great 
advantage — cost leadership is difficult to reach for young and small firms due to the lack of experience and low economies of scale, and thus start-ups rather pursue a strategy of product differentiation. Moreover, high-tech start-ups choose quality-related differentiation strategies more often than non-high-tech firms-specialisation is obviously most prevalent in high-tech industries.

A number of research questions arise with respect to market structure and entry strategies. For instance, why do strategies differ? Which entrepreneurs opt for which entry strategy? Are some strategies more promising for some start-ups than for others? And do different strategies lead to different degrees of company success in the short run (establishment in the market) or in the long run (company growth)? The detailed questionnaire of the KfW/ZEW Start-up Panel contains a broad set of variables suited to address these questions. Inter alia, firms are regularly asked about their investment behaviour and their innovativeness. Moreover, the 2008 questionnaire records the number of competitors, fields of competitive advantage and perceived price-performance ratios, technology fields relevant for start-ups, but also personal start-up motives of the entrepreneurs.

\subsection{Innovation, Research and Development in Young Firms}

Innovative start-ups are often considered most beneficial to the process of creative destruction and thus to the dynamics of economic development. However, little is known as to the nature of innovations in start-up firms. On the one hand, all start-ups meet the conventional minimum requirement of innovativeness - all processes and products of a newly founded firm are, by definition, new to the firm. On the other hand, only a minority of entrepreneurial projects are innovative in a narrower sense (Kohn and Spengler 2009). Following the recommendations of the Oslo manual (OECD 2005), participants in the KfW/ZEW Start-up Panel were asked whether they introduced products which were new to the world market, new in Germany, or new in the region the start-up is located in.

$$
<<<\text { Table } 4 \text { near here }>>>
$$

Column (1) of Table 4 shows that on average one out of five start-ups (18\%) introduced products new to the market at all. Only a small share of 3\% introduced world novelties. Again, there is a considerable heterogeneity across sectors: Start-ups in cutting-edge technology and high-technology manufacturing but also firms from the software industry are disproportionately innovative. Innovativeness is intrinsically linked to research and development (R\&D). 
As can be inferred from column (2) of Table 4, firms from high-tech industries carry out R\&D activities more often, and more often in a continuous way.

The descriptive picture calls for a sophisticated analysis of the impact of $R \& D$ on young firms’ innovativeness. How about possible endogeneity of R\&D? And how about the role of product versus process innovations? Are there differences with respect to $R \& D$ and innovation between start-ups and more "mature" firms?" As Niefert and Zimmermann (2009) recently pointed out, the link between $R \& D$ behaviour and innovativeness of incumbent firms changes over the life cycle. Ultimately, one should study the impact of innovativeness on start-up success. Do high-tech firms live up to their promises of growth and success in the medium and long run? The panel nature of the KfW/ZEW Start-up Panel will allow researchers to address these issues in future research. In addition, the first wave puts an emphasis on R\&D and measures for protection of intellectual property. Participants revealed not only whether they did $R \& D$, but also provided information on $R \& D$ expenditure, gave the number of patents or trademarks, and reported on the importance of these measures for the firm.

\subsection{Labour Demand of Start-Ups}

It is well known that employment in young and small firms is more volatile than employment in older and larger firms (van Praag and Versloot 2007). Yet evidence on the specific nature and the dynamics of employment within start-up firms has been sparse so far. Most start-ups do not employ any workers except for the founders themselves. $60 \%$ of all start-ups in the KfW/ZEW Start-up Panel start without employees and the average number of persons employed at time of the start-up-including founders—is 3.5 (Gottschalk et al. 2008). Moreover, the size distribution of those firms with employees is heavily skewed to the right.

$$
<<<\text { Table } 5 \text { near here }>>>
$$

Column (1) of Table 5 shows the extent to which start-ups employ different types of employees. For example, one out of five firms (21\%) starts with at least one full-time employee subject to social security contributions, and $14 \%$ rely on family members of the founders. In light of the high number of firms without any employees and the small number of larger firms, founders' share in total employment created amounts to of 38\% (column (2) of Table 5). Another $18 \%$ of positions at the time of the start-up are filled with full-time employees subject to social security contributions. On the other hand, the share of part-timers, marginally employed

\footnotetext{
${ }^{4}$ Innovativeness and R\&D of incumbent firms in Germany have been studied in the past based on data from the KfW SME panel (KfW-Mittelstandspanel, Lo and Reize 2008) or the Mannheim Innovation Panel (Rammer et al. 2005).
} 
workers, freelancers, interns, and temporary employees sum up to 37\%. Thus, firms make use of flexible work practices already at an early stage.

The skill structure of employees provides insights into the human capital involved in start-up firms. On average, more than a third (37\%) of all employees in start-up firms work in occupations that do not require a vocational training, while only a small minority (7\%) of occupations requires a university degree (Gottschalk et al. 2008). Yet start-ups in high-tech industries are more skill-intensive than start-ups in non-high-tech industries (Figure 2): In cutting-edge technology and high-tech manufacturing, software, and technology-intensive services the share of occupations for university graduates averages to $22 \%$.

$<<<$ Figure 2 near here $>>>$

Again, the comparison of new firms with incumbent ones is important in order to assess the relative position of start-ups with respect to labour demand. ${ }^{5}$ In this context, the KfW/ZEW Start-up Panel offers two additional assets. First, the questionnaire accounts for within-year fluctuation of employment. Thus, analyses of employment dynamics are not restricted to using aggregate numbers from end-of-year employment stocks. Second, the panel captures human capital information of both employees and founders and, therefore, combines the advantages of individual-level population surveys and firm-level data.

The set of structural employment information renders the KfW/ZEW Start-up Panel suitable for detailed analyses of human capital and labour demand of young firms. In addition, the panel nature of the data allows for analyses of the medium and long-term employment effects of business start-ups. Results from the start-up panel can thus be expected to mitigate today's lack of evidence on crowding out effects of new venture creation as to existing jobs and on the sustainability of created jobs.

\subsection{Investment and Financing Strategies}

Start-up firms invest into machinery, real estate, inventory, etc. In addition, they have to cover operating costs such as rent and leasing rates or labour costs. In order to comprehend the involved financing decisions, the questionnaire follows a nested approach (see also Kohn and Spengler 2008a). At a first stage, it discriminates the use of financial means and tangible assets such as an owner's car or an own computer. 95\% of all start-ups in the KfW/ZEW Start-

\footnotetext{
${ }^{5}$ There is a lively debate in the literature on whether SMEs create more jobs than larger firms. The empirical evidence so far is mixed (Engel and Trax 2008, Wagner 2007). Results from the KfW/ZEW Start-up panel may not only cast additional light on the firm-size issue, but also provide information as to whether very young or older firms create more jobs.
} 
up Panel finance investments during their first year, and 56\% additionally use tangible assets (Gottschalk et al. 2008). ${ }^{6}$

At a second stage, three types of financial resources are distinguished: revenue generated from sales, founders' own means (such as personal savings used for firm start-up), and capital from external third-party providers. 68\% of all firms founded in the year 2007 generated sales revenue already within the same calendar year. Among these firms, the average revenue (Euro 50,900) was much smaller than the corresponding median (Euro 17,100). Right-skewed distributions are also observed for the use of founders' own financial means and capital from third-party providers. $62 \%$ of all start-ups stood to the benefit from founders' own resources and only about one third (35\%) of all start-ups relied on external providers. Financing amounts vary considerably across industries. Manufacturing firms, both high-tech and nonhigh-tech, have the highest financing needs due to their relatively high capital intensities.

At the third stage, the questionnaire differentiates sources of external financing (Figure 3). Bank loans_current account facilities as well as more long-term-oriented loans-and subsidies from the Federal Employment Agency are used most often. However, the latter are relatively small and only make up for a small volume share (about $4 \%$ of the total volume of external financing). Traditional bank loans account for the lion's share of external financing (volume share of $48 \%$ in total). Again, there is considerable heterogeneity in the importance of the different sources across industries. Perhaps most notably, the volume share of venture capital averages to merely $3 \%$ in non-high-tech industries, but is much higher in high-tech manufacturing (17\%) and high-tech services (22\% of the total volume of external financing).

$$
<<<\text { Figure } 3 \text { near here }>>>
$$

The detailed questions on start-up financing in combination with the broad set of firm specifics — such as sales and profits generated in each year after firm foundation-render the KfW/ZEW Start-up Panel a promising tool for addressing a number of prevailing research questions. For instance, what are the determinants of financing strategies? Do start-ups follow a pecking order regarding their financing behaviour (Myers and Majluf 1984)? And in turn, what is the impact of financing strategies on the development of firms? Are there bottlenecks and financing constraints? While it is well-known that financial restrictions are binding in the

\footnotetext{
${ }^{6}$ Note that these numbers - and the entire financing behaviour of the more substantial start-up firms covered by the KfW/ZEW Start-up Panel-differ from the more small-scaled financing behaviour of business starters covered by the population-representative KfW Start-up Monitor. In the latter case, for example, only two thirds (62\%) of all starters in the year 2007 used financial means for their start-up project, while another quarter relied on existing tangible assets only (Kohn and Spengler 2008b).
} 
context of the start-up decision, ${ }^{7}$ little is known about the crucial first years after the start-up. Are information asymmetries binding for young firms (Stiglitz and Weiss 1981)? Again, the sampling strategy of the KfW/ZEW Start-up Panel allows scrutinising different financial conditions in different industries.

\subsection{Survival of Young Firms}

A very important research topic that has been examined only insufficiently in the existing literature is the analysis of start-up survival, which is often considered a minimum criterion of start-up success (Brüderl et al. 1992, 2007). ${ }^{8}$ The survival status of firms in the KfW/ZEW Start-up Panel which do no longer respond to the telephone survey will be investigated by members of Creditreform as explained in section 2.5 above. On the one hand, this provision will allow us to tell apart simple non-response by existing firms and firm mortality. On the other hand, forced liquidations (bankruptcies), voluntary liquidations and take-overs by other companies will be distinguished among abandoned firms.

This additional asset of the KfW/ZEW Start-up Panel will enable researchers, first, to take account of a survival bias when carrying out econometric analyses with data of existing firms. Second, it will be possible to track firms in the years before market exit and to identify determinants of firm mortality by means of survival analysis. Competing risk models can be reasonably employed in order to scrutinise the different types of start-up mortality. The full potential of this approach will be tapped in coming years over time-and again, the broad set of covariates collected in each of the panel waves will spur the analysis.

\section{Provision of Data}

\subsection{Data Protection}

Particular attention is given to data protection issues in order to fulfil statutory requirements and to ensure data quality. Confidentiality of revealed individual information is an essential prerequisite for firms to repeatedly take part in the survey, and prevents high numbers of unit and item non-response or inexact answers. The $\mathrm{ZEW}$, which is responsible for the realisation of the questionnaire, and ZEM — the institute carrying out the telephone interviews-solely

\footnotetext{
${ }^{7}$ Cf. Evans and Jovanovic (1989) and the literature cited in Parker (2004).

${ }^{8}$ See van Praag (2003) for a detailed overview of historical lines of argument and recent empirical findings on firm survival.
} 
know the addresses of the firms and names of the interviewed persons. The name and the contact information of an interviewee are registered only if the person explicitly agrees to this. Contact data are only used for re-establishing contact in the following panel waves and for delivering reports with research results stemming from the survey. The two remaining cooperation partners, KfW and Creditreform, receive the survey data from the ZEW without firms' names and addresses and without names and email addresses of the contact persons. This means, the survey data are formally anonymised.

The utilisation of all firm records is restricted to scientific purposes and is only allowed to those employees of KfW, Creditreform and ZEW who are involved in associated research projects of the KfW/ZEW Start-up Panel. Neither Creditreform nor KfW nor ZEW are allowed to publish any individual data. Firm characteristics are published only in aggregated form, ensuring that firms cannot be re-identified by a third party.

The rules of data protection also guarantee that Creditreform will not match the survey data with their own business or process data, as this would presume a re-identification of firms and imply a non-scientific exploitation of the data. Employees of Creditreform will not use the survey data for credit ratings of the participating firms. KfW will not use the survey data for credit negotiations. That is, data protection is fulfilled also within the cooperating institutes. Scientific and data protection standards are in all probability complied.

\subsection{Data Access}

Creditreform, KfW and ZEW utilise the survey data for own research projects, partly in cooperation with each other. These research projects cover basic scientific analyses as well as commercial studies ordered by third parties (government departments, EU institutions, private enterprises etc.). In addition, the data of the KfW/ZEW Start-up Panel will be made available for interested researchers outside the co-operating institutes. Scientific-use-files of the yearly surveyed cross-sections of the KfW/ZEW Start-up Panel will be provided to external scientists. These data will be allowed to be used for non-commercial basic research only. Teaching purposes will also be excluded. Individual information about the founders of the firms will not be part of the scientific-use-files. Researchers will have to apply for external use of the scientific-use-files and all project partners (KfW, Creditreform and ZEW) will have to approve it. A contract specifying the intended research project and involved researchers will be signed in each case. 
Separate scientific-use-files will be generated for each cross-section of the survey with a delay of three years, respectively. The time lag between realisation of the survey and dissemination to external scientists is another attribute to data protection. The re-identification risk decreases when only former information about firms is available for external users. Since the KfW/ZEW Start-up Panel covers very young firms-in contrast to, e.g., the older firms covered by the Mannheim Innovation Panel—some alterations of known anonymisation measures will be necessary for this project. Developing appropriate methods for mastering this challenge will be the subject of next years' investigations.

Different methods will be used to prevent single firms from being identified. The ZEW has already experienced the anonymisation of firm micro-data in producing scientific-use-files of the Mannheim Innovation Panel (see Janz et al. 2001). In general, the anonymisation techniques used there will also be applicable for this project. For example, variables measured in money amounts are available only as ratios to sales or employees or are made anonymous using the disguised random factor method, i.e., these variables are multiplied by a firmspecific unique random factor. Data sets of firms which could be identified quite easily are completely removed from the data. In case of the KfW/ZEW Start-up Panel, modifications of the known techniques will be necessary to avoid re-identification.

\section{Conclusion}

Since the year 2008, the Centre for European Economic Research (ZEW), KfW Bankengruppe (KfW) and Creditreform are cooperating to set up the KfW/ZEW Start-up Panel, a unique panel data set of newly founded firms in Germany. The panel builds on yearly telephone interviews with approximately 6,000 start-ups. Each year's survey is based on a random sample drawn from the Creditreform database. The sample is stratified by three criteria: year of firm formation, industrial sector, and whether or not the firm has been promoted by KfW. Each year, firms that have been founded within three years prior to the year of the survey are selected for the sample. In order to build up a panel data set, firms that participated in a previous wave of the survey will be contacted during the subsequent years as long as they are eight years of age or younger.

In comparison to related existing data sets, the start-up panel has a number of important advantages: First, economically independent firms are the statistical units of the start-up panel, whereas several other data sets either include economically dependent branches or establishments, or regard the person of the entrepreneur as the statistical unit. Second, the start-up 
panel tracks firms from their first year of existence. In contrast, other databases observe firms only after they have exceeded certain threshold values, e.g., after hiring the first employee subject to social insurance contributions. A third advantage of the KfW/ZEW Start-up Panel is the fact that it covers almost all industry sectors. Due to the relatively large target size of the net sample, the panel comprises data on a considerable number of start-ups for each of the included sectors. Start-ups in high-tech industries are explicitly oversampled. Finally, the most important distinction of the start-up panel from other data sets is that it will track young firms over an eight-year period, allowing researchers to analyse changes within firms during this decisive period of a firm's life. The panel nature of the data set will permit the application of sophisticated panel data econometrics in order to appropriately account for firm-specific heterogeneity—which is not possible when using currently available data sets.

The KfW/ZEW Start-up Panel therefore provides unique opportunities regarding research questions whose answers require a panel data set. For example, it is still an open question when and in which way firms replace one source of finance by another (e.g., business angel financing may be replaced by venture capital at some point in a firm's lifecycle) and how this affects the long-term performance of the firm. Similarly, so far we do not know when and to which extent new firms convert part-time employees, marginally employed workers or freelancers-which may have proven sufficiently flexible during the start-up period-into fulltime employees. It is the primary, long-term objective of the KfW/ZEW Start-up Panel to build up a data set that is suitable for analyses of changes like these.

In order to fully exploit the research potential of the KfW/ZEW Start-up Panel, there are two versions of the yearly questionnaire. Firms contacted for the first time are asked a broad range of structural information. Firms contacted repeatedly in subsequent years provide additional information on their development. Information on basic aspects such as sales, investment, financing, labour demand, innovation and R\&D activities, is collected every year. In addition, the yearly questionnaires put different emphasis on changing main foci.

Another asset of the KfW/ZEW Start-up Panel originates from the fact that the survival status of all firms that have ever participated in the panel will be identified reliably. Staff members of Creditreform will directly investigate all firms that cannot be re-contacted in the course of the telephone survey and for which there is no indication of closure in the Creditreform database. As a consequence, it will be possible to distinguish firm mortality and other reasons preventing repeated contact (such as changes of firm name or telephone number, or relocations). This information will allow researchers, first, to account for a survival bias when carry- 
ing out econometric analyses with data of existing firms and, second, to track the development of firms in the years before market exit.

On the one hand, the unique characteristics of the KfW/ZEW Start-up Panel will spur research on newly founded firms in Germany. Scientific-use-files of the KfW/ZEW Start-up Panel will be made available for intense use by external researchers. On the other hand, the data are also suitable for international comparative research. For example, the design of the Kauffman Firm Survey for the United States (Robb et al. 2009) is similar to the KfW/ZEW Start-up Panel in that it tracks newly founded firms over more than six years and also focuses on firm strategies, financing, innovation and labour demand. 


\section{References}

Agarwal, R., and D. B. Audretsch (2001), Does entry size matter? The impact of the life cycle and technology on firm survival, Journal of Industrial Economics, XLIX(1), 21-43.

Almus, M., D. Engel and S. Prantl (2000), The "Mannheim Foundation Panels" of the Centre for European Economic Research (ZEW), ZEW Documentation 00-02, Zentrum für Europäische Wirtschaftsforschung, Mannheim.

Audretsch, D. B., and M. Fritsch (2003), Linking entrepreneurship to growth: The case of West Germany, Industry and Innovation, 10(1), 65-73.

Bellmann L., G. Dörfer, W. Dostal, J. Kühl, M. Lahner, P. Schnur, E. Ulrich and M. Wolfsteiner (1991), Das IAB-Betriebspanel: Ansatz und Aufbau, Mitteilungen aus der Arbeitsmarkt- und Berufsforschung, 24(3), 514-530.

Birch, D. L. (1989), Change, innovation, and job generation, Journal of Labour Research, 10(1), 33-38.

Brüderl, J., P. Preisendörfer and R. Ziegler (1992), Survival Chances of Newly Founded Business Organizations, American Sociological Review, 57, 227-242.

Brüderl, J., P. Preisendörfer and R. Ziegler (2007), Der Erfolg neu gegründeter Betriebe. Eine empirische Studie zu den Chancen und Risiken von Unternehmensgründungen, 3rd, ext. edn., Berlin: Duncker \& Humblot.

Engel, D., and M. Trax (2008), Der Beschaeftigungsbeitrag kleiner und mittlerer Unternehmen nach der EU-Definition, Erste Ergebnisse auf Basis des IAB-Betriebspanels für Deutschland, Jahrbücher für Nationalökonomie und Statistik, 228(1), 64-83.

Evans, D. S., and B. Jovanovic (1989), An Estimated Model of Entrepreneurial Choice under Liquidity Constraints, Journal of Political Economy, 97, 808-827.

Gottschalk, S., H. Gude, S. Kanzen, K. Kohn, G. Licht, K. Müller, M. Niefert and H. Spengler (2008), KfW/ZEW-Gründungspanel für Deutschland - Beschäftigung, Finanzierung und Markteintrittsstrategien junger Unternehmen, Creditreform, KfW, ZEW (eds.), Mannheim.

Grupp, H., and H. Legler (2000), Hochtechnologie 2000 - Neudefinition der Hochtechnologie für die Berichterstattung zur technologischen Leistungsfähigkeit Deutschlands, research report for the Federal Ministry of Education and Research, Karlsruhe, Hannover.

Janz, N., G. Ebling, S. Gottschalk and H. Niggemann (2001), The Mannheim Innovation Panels (MIP and MIP-S), Schmollers Jahrbuch, 121(1), 123-129.

Kohn, K., and H. Spengler (2008a), Finanzierungsstruktur von Existenzgründungen in Deutschland, FINANZ BETRIEB, 10, 72-76.

Kohn, K., and H. Spengler (2008b), KfW-Gründungsmonitor 2008. Gründungen in Deutschland: weniger aber besser - Chancenmotiv rückt in den Vordergrund, KfW Bankengruppe, Frankfurt am Main.

Kohn, K., and H. Spengler (2009), KfW-Gründungsmonitor 2009. Abwärtsdynamik im Gründungsgeschehen gebremst - weiterhin wenige innovative Projekte, KfW Bankengruppe, Frankfurt am Main.

Lo, V., and F. Reize (2008), KfW-Mittelstandspanel 2008. Mittelstand - auch kleine Unternehmen - erfolgreich im Ausland!, KfW Bankengruppe, Frankfurt am Main. 
Metzger, G., M. Niefert and G. Licht (2008), High-Tech-Gründungen in Deutschland Trends, Strukturen, Potenziale, research report (in cooperation with Microsoft Germany), Zentrum für Europäische Wirtschaftsforschung, Mannheim.

Myers, S. C., and N. S. Majluf (1984), Corporate Financing and Investment Decisions When Firms Have Information That Investors Do not Have, Journal of Financial Economics, 13, 187-221.

Niefert, M., and V. Zimmermann (2009), Die Dynamik im Innovationsverhalten kleiner und mittlerer Unternehmen, in: KfW, Creditreform, IfM, RWI, ZEW (eds.), MittelstandsMonitor 2009, Frankfurt am Main, 107-133.

OECD (2005), Oslo Manual - Guidelines for Collecting and Interpreting Innovation Data, 3rd edn., Organisation for Economic Co-Operation and Development and Statistical Office of the European Communities, Paris.

Parker, S. C. (2004), The Economics of Self-Employment and Entrepreneurship, Cambridge: University Press.

Porter, M. E. (1980), Competitive Strategy: Techniques for Analyzing Industries and Competitors, New York: The Free Press.

Prantl, S. (2001), Bankruptcy, subsidized loans, and exit decisions of start-up firms, dissertation, University of Mannheim.

Rammer, Ch., B. Peters, T. Schmidt, B. Aschhoff, T. Doherr and H. Niggemann (2005), Innovationen in Deutschland, ZEW Wirtschaftsanalysen, 78, Baden-Baden.

Robb, A., J. Ballou, D. DesRoches, F. Potter, Z. Zhao and E. J. Reedy (2009), An Overview of the Kauffman Firm Survey - Results from the 2004-2007 Data, Ewing Marion Kauffman Foundation, Kansas City.

Schulte, R. (2001), Konzeption und Methodik des Gründerpanels Nordrhein-Westfalen, in: H. Klandt, K. Nathusius, J. Mugler and H. Heil (eds.), Gründungsforschungsforum 2000, Dokumentation des 4. G-Forums, Eul, Lohmar and Köln, 47-62.

Sternberg, R., U. Brixy and C. Hundt (2007), Global Entrepreneurship Monitor (GEM) Länderbericht Deutschland 2006, Global Entrepreneurship Research Association, Hannover/Nürnberg.

Stiglitz, J., and A. Weiss (1981), Credit Rationing in Markets with Imperfect Information, American Economic Review, 71, 393-410.

Tchouvakhina, M., and C. Hofmann (2003/04), The KfW Start-up Monitor - An Instrument for In-Depth Analysis of Start-up Activity in Germany, RWI: Mitteilungen, 54/55(3-4), 267-285.

Van Praag, C. M. (2003), Business Survival and Success of Young Small Business Owners, Small Business Economics, 21, 1-17.

Van Praag, C. M., and P. H. Versloot (2007), What Is the Value of Entrepreneurship? A Review of Recent Research, Small Business Economics, 29, 351-382.

Wagner, J. (2007), Jobmotor Mittelstand? Arbeitsplatzdynamik und Betriebsgröße in der Westdeutschen Industrie, Working Papers Series in Economics 47, Universität Lüneburg. 
Table 1: Composition of Industry Sectors Covered by the KfW/ZEW Start-up Panel

\begin{tabular}{|c|c|c|}
\hline & Sector & NACE Rev. 1 \\
\hline & \multicolumn{2}{|l|}{ high technology industries } \\
\hline 1 & cutting-edge technology manufacturing & $\begin{array}{l}\text { 23.30, 24.20, 24.41, 24.61, 29.11, 29.60, } \\
\text { 30.02, 31.62, 32.10, 32.20, 33.20, 33.30, } \\
35.30\end{array}$ \\
\hline 2 & high-technology manufacturing & $\begin{array}{l}\text { 22.33, 24.11, 24.12-4, 24.17, 24.30, 24.42, } \\
\text { 24.62-4, 24.66, 29.12-4, 29.31-2, 29.40, } \\
\text { 29.52-6, 30.01, 31.10, 31.40, 31.50, 32.30, } \\
\text { 33.10, 33.40, 34.10, 34.30, 35.20 }\end{array}$ \\
\hline 3 & technology-intensive services & 64.2, 72 (without 72.2), 73.1, 74.2, 74.3 \\
\hline \multirow[t]{2}{*}{4} & software supply and consultancy & 72.2 \\
\hline & non-high-tech industries & \\
\hline 5 & non-high-tech manufacturing & $15-37$ (without sectors $1+2$ ) \\
\hline 6 & skill-intensive services (non-technical consulting services) & 73.2, 74.11-4, 74.4 \\
\hline 7 & other business-oriented services & $\begin{array}{l}71.1,71.2,71.3,74.5-74.8 \text { (without } \\
74.84 .7), 90,64.1,61,62,60.3,63.1,63.2 \\
63.4\end{array}$ \\
\hline 8 & consumer-oriented services & $\begin{array}{l}55,70,71.4,92,93,80.4,65-67,60.1 \\
60.2,63.3\end{array}$ \\
\hline 9 & construction & 45 \\
\hline 10 & wholesale and retail trade (without trade agents) & $50-52$ (without 51.1) \\
\hline
\end{tabular}

Cutting-edge manufacturing technology: manufacturing industries with average R\&D expenditure > 8.5\% of total sales. High-technology manufacturing: manufacturing industries with average R\&D expenditure $3.5-8.5 \%$ of total sales. Source: Grupp and Legler (2000), own classification. 
Table 2: Composition of Gross and Net Sample 2008

\begin{tabular}{|c|c|c|c|c|c|c|c|c|}
\hline \multirow{2}{*}{$\begin{array}{l}\text { Year of Start-up } \\
\text { Sector }\end{array}$} & \multicolumn{2}{|c|}{2005} & \multicolumn{2}{|c|}{2006} & \multicolumn{2}{|c|}{2007} & \multicolumn{2}{|c|}{ total } \\
\hline & Gross & Net & Gross & Net & Gross & Net & Gross & Net \\
\hline $\begin{array}{l}\text { cutting-edge technology } \\
\text { manufacturing }\end{array}$ & 370 & 71 & 346 & 77 & 202 & 55 & 918 & 203 \\
\hline $\begin{array}{l}\text { high-technology manu- } \\
\text { facturing }\end{array}$ & 707 & 138 & 780 & 177 & 541 & 120 & 2,028 & 435 \\
\hline $\begin{array}{l}\text { technology-intensive } \\
\text { services }\end{array}$ & 2,134 & 398 & 2,102 & 438 & 2,045 & 472 & 6,281 & 1,308 \\
\hline software & 1,549 & 283 & 1,265 & 303 & 696 & 221 & 3,510 & 807 \\
\hline $\begin{array}{l}\text { non-high-tech manufac- } \\
\text { turing }\end{array}$ & 900 & 170 & 787 & 177 & 496 & 155 & 2,183 & 502 \\
\hline skill-intensive services & 421 & 86 & 375 & 99 & 297 & 87 & 1,093 & 272 \\
\hline $\begin{array}{l}\text { other business-oriented } \\
\text { services }\end{array}$ & 460 & 93 & 427 & 96 & 304 & 92 & 1,191 & 281 \\
\hline $\begin{array}{l}\text { consumer-oriented ser- } \\
\text { vices }\end{array}$ & 1,100 & 173 & 1,100 & 187 & 764 & 176 & 2,964 & 536 \\
\hline construction & 900 & 184 & 864 & 188 & 619 & 168 & 2,383 & 540 \\
\hline $\begin{array}{l}\text { wholesale and retail } \\
\text { trade }\end{array}$ & 1,100 & 202 & 1,100 & 225 & 800 & 197 & 3,000 & 624 \\
\hline total & 9,641 & 1,798 & 9,146 & 1,967 & 6,764 & 1,743 & 25,551 & 5,508 \\
\hline
\end{tabular}

Number of firms in sector-by-year cells.

Source: KfW/ZEW Start-up Panel, first wave 2008 (Gottschalk et al. 2008).

Table 3: Response Code of Gross Sample

\begin{tabular}{lcc}
\hline & Number of Firms & Share in Percent \\
\hline completed interview & $5,510^{\mathrm{a}}$ & 25.52 \\
incomplete interview & 1,216 & 5.63 \\
open interview appointment & 651 & 3.02 \\
interview denied & 6,239 & 28.90 \\
firm other than indicated & 1,434 & 6.64 \\
firm no longer exists & 884 & 4.10 \\
no independent start-up & 509 & 2.36 \\
start-up year other than 2005/2006/2007 & $5,144^{\mathrm{b}}$ & 23.83 \\
\hline total & 21,587 & 100.00 \\
\hline
\end{tabular}

${ }^{\mathrm{a}}$ Due to two duplicates in the data set, the final number of interviews as reported in Table 2 amounts to 5,508 firms.

${ }^{b}$ See footnote 3 for an explanation of the high number of firms with this response code.

Source: KfW/ZEW Start-up Panel, first wave 2008 (Gottschalk et al. 2008). 
Figure 1: Competitive Advantages over Main Competitors

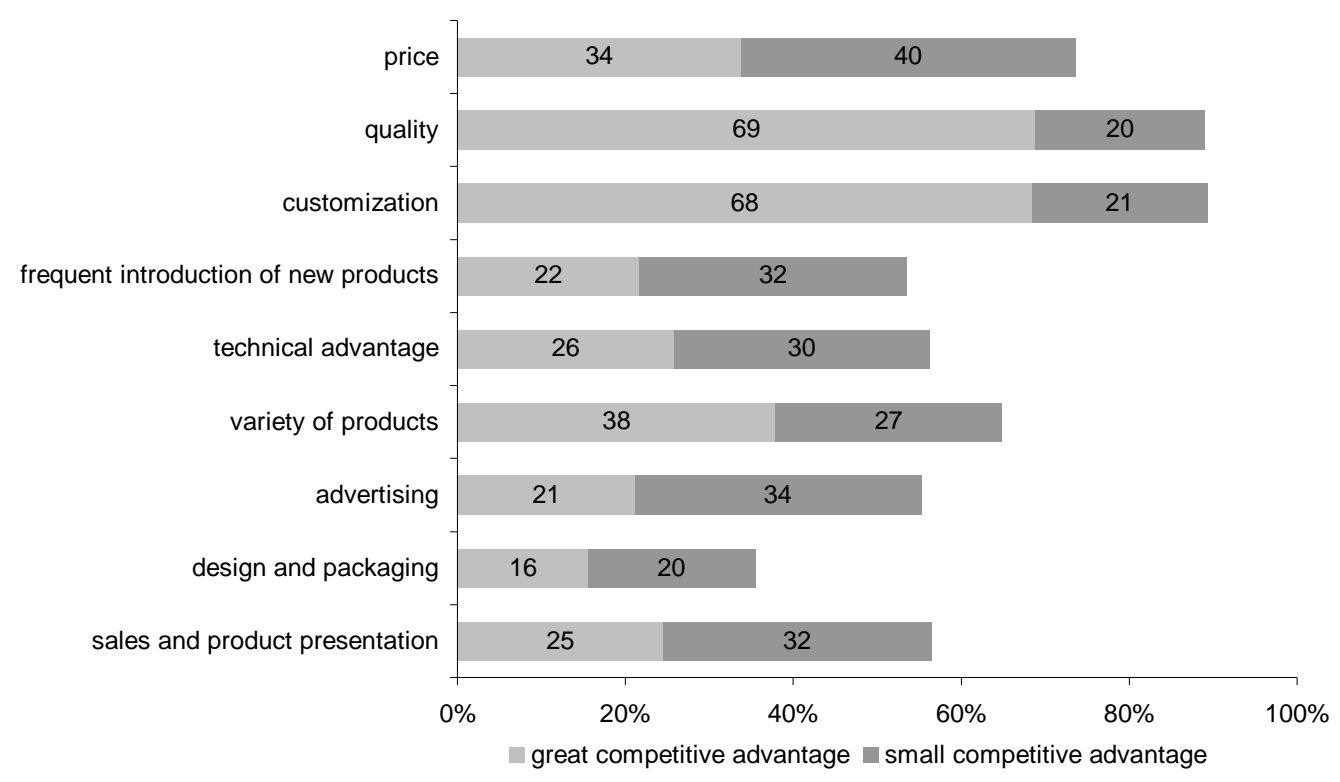

Shares in percent of start-ups.

Source: KfW/ZEW Start-up Panel, first wave 2008 (Gottschalk et al. 2008).

Table 4: Products new to the Market and Research and Development Activities, by Industry

(1)

Introduction of products new to the market

\begin{tabular}{|c|c|c|c|c|c|c|c|}
\hline & \multicolumn{4}{|c|}{ market } & \multicolumn{3}{|c|}{ activities } \\
\hline & $\begin{array}{c}\text { world } \\
\text { market }\end{array}$ & $\begin{array}{l}\text { Ger- } \\
\text { many }\end{array}$ & region & no & continuous & occasional & no \\
\hline $\begin{array}{l}\text { cutting-edge technology } \\
\text { manufacturing }\end{array}$ & 16 & 12 & 3 & 69 & 33 & 17 & 50 \\
\hline $\begin{array}{l}\text { high-technology manu- } \\
\text { facturing }\end{array}$ & 11 & 13 & 8 & 68 & 23 & 19 & 58 \\
\hline $\begin{array}{l}\text { technology-intensive } \\
\text { services }\end{array}$ & 6 & 10 & 7 & 77 & 16 & 15 & 69 \\
\hline software & 9 & 12 & 7 & 72 & 30 & 16 & 54 \\
\hline $\begin{array}{l}\text { non-high-tech manufac- } \\
\text { turing }\end{array}$ & 6 & 8 & 10 & 76 & 13 & 15 & 72 \\
\hline skill-intensive services & 2 & 12 & 10 & 76 & 16 & 9 & 75 \\
\hline $\begin{array}{l}\text { other business-oriented } \\
\text { services }\end{array}$ & 4 & 6 & 12 & 78 & 6 & 10 & 84 \\
\hline $\begin{array}{l}\text { consumer-oriented ser- } \\
\text { vices }\end{array}$ & 0 & 5 & 10 & 85 & 10 & 8 & 82 \\
\hline construction & 1 & 2 & 5 & 92 & 2 & 5 & 93 \\
\hline wholesale and retail trade & 5 & 5 & 8 & 82 & 7 & 7 & 86 \\
\hline total & 3 & 6 & 9 & 82 & 9 & 9 & 82 \\
\hline
\end{tabular}

Shares in percent of start-ups.

Source: KfW/ZEW Start-up Panel, first wave 2008 (Gottschalk et al. 2008). 
Table 5: Composition of Employment at Time of Start-up

(1)

Share of firms employing ...

(2)

Total employment created

founders

100.0

37.7

full-time employees subject to social insur-

ance contributions

17.7

part-time employees subject to social insur-

ance contributions

9.8

marginally employed workers (Mini-Jobs)

18.1

18.5

family members of founders

14.0

5.9

apprentices

3.3

1.3

freelancers

8.3

10.1

interns

3.1

1.6

temporary employees (Leiharbeitskräfte)

1.0

1.3

Total

100.0

Shares in percent.

Column (1): By definition, all start-ups employ the founders themselves. In addition, 20.8\% of all start-ups employ full-time employees subject to social insurance contributions, for instance.

Column (2): Positions filled by founders themselves amount to $37.7 \%$ of total employment created.

Source: KfW/ZEW Start-up Panel, first wave 2008 (Gottschalk et al. 2008).

\section{Figure 2: Skill Structure of Employees in Start-Ups}

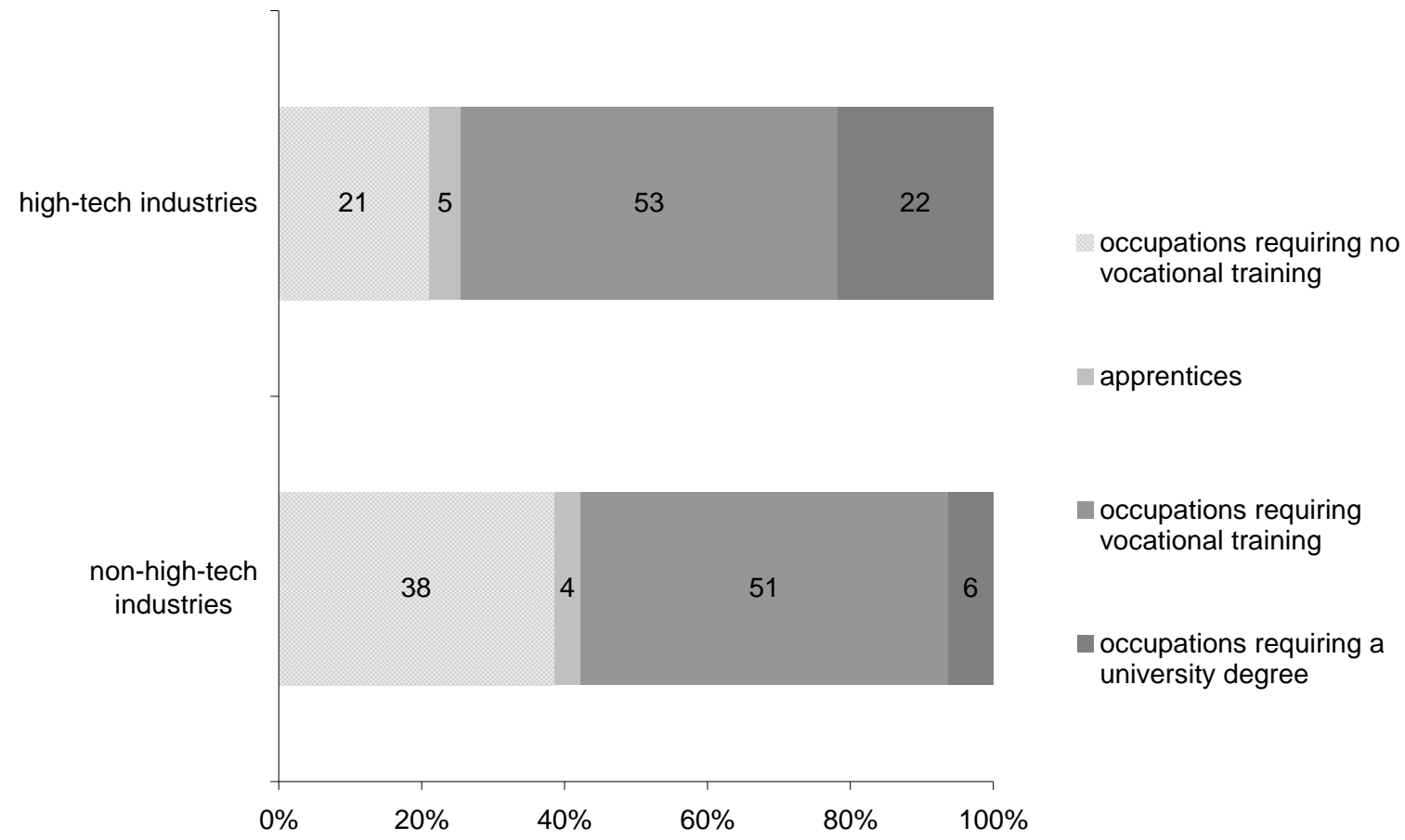

Shares in percent of start-ups. See Table 1 for industry classification.

Source: KfW/ZEW Start-up Panel, first wave 2008 (Gottschalk et al. 2008). 
Figure 3: Frequency and Volume of External Financing Sources

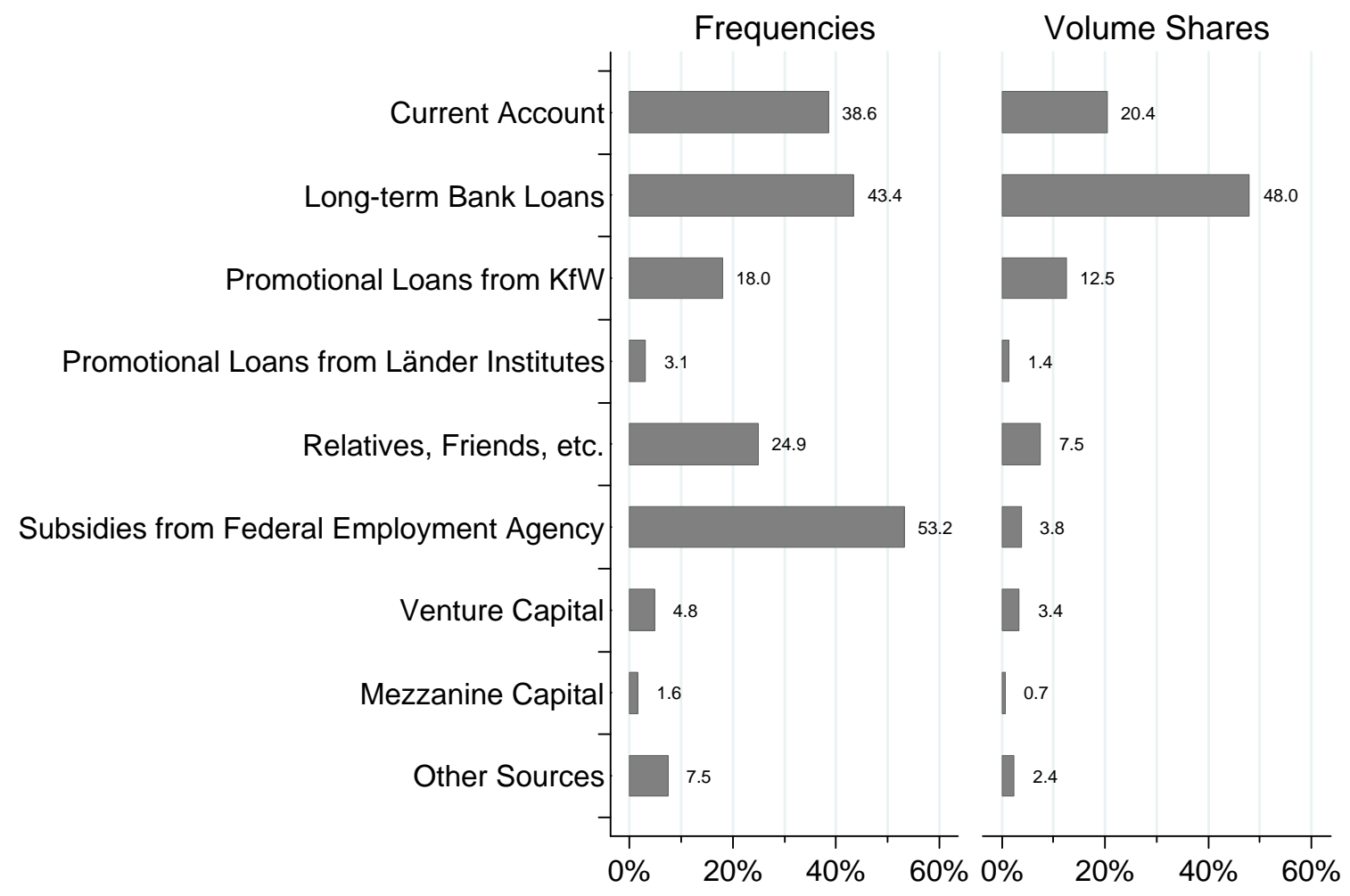

Left column: use of different financing sources during start-up year (shares in percent of start-ups, multiple answers); frequencies conditional on the use of external financing. Right column: volume shares in percent of external financing. Start-ups in 2007.

Source: KfW/ZEW Start-up Panel, first wave 2008 (Gottschalk et al. 2008). 